Schmidt M., Doerre A. (2011): Changing meanings of Kyrgyzstan's nut forests from colonial to post-Soviet times. In: Area 43(3), 288-296. DOI: doi: 10.1111/j.1475-

4762.2010.00988.x.

\title{
Changing meanings of Kyrgyzstan's nut forests from colonial to post-Soviet times
}

\author{
Matthias Schmidt and Andrei Doerre
}

Discourses shape the perception, conservation and utilisation of natural resources. This can be seen in the case of the globally unique walnut-fruit forests of southern Kyrgyzstan. This article shows the historical change of the discourse on protection and utilisation of these forests from the times of Russian colonialism and Soviet socialism up to present day post-Soviet capitalism. Due to the abundance of these forests, protection concepts were developed long ago with the aim of implementing 'proper' utilisations. By applying an interpretative discourse analytical method, the thesis will be proved that historical concepts for forest protection did not arise from the understanding of an intrinsic value of nature as often assumed, but instead were formed by powerful actors through pragmatic arguments to create control systems over this natural resource. Consequently, the present status of the walnutfruit forests is a result of the interplay of natural processes and anthropogenic interventions. The conflict-laden relation between the current socioeconomic situation of the region and specific patterns of the conservation discourse becoming apparent recently make this article relevant. If the forests' structural significance for local and regional economies is undervalued or ignored, concepts targeting the goal of restoring the forests in a natural state or operating with the basic objective of protecting biodiversity and genetic resources might generate new rivalries and income conflicts. Rather, in view of the long-term human impact, the forests must be understood primarily as a cultural landscape, and consequently the aims, instruments and terminologies of the protection concepts have to be adapted to this understanding and reformulated with the involvement and participation of local stakeholders.

\section{Introduction}

After the opening of the Soviet Union at the end of the Cold War, Western scientists and environmentalists became aware not only of many ecologically disastrous legacies of 'actually existing socialism' (Pickles and Smith 1998) but also of an impressive variety of apparently untouched natural spaces and unique ecosystems. One such singularity among the Central Asian deserts, steppes and high mountains is located in the southwestern Tien Shan: a relatively small area of mixed forests, mainly walnut and various species of wild fruit. In view of global species extinction and the predominant agenda of protecting biodiversity hotspots, the high species diversity of these walnutfruit forests has stimulated efforts to ensure their long-term survival and protection (Blaser et al. 1998; Gottschling et al. 2005; SAEPFUGKR 2010). Far from being an unpopulated natural landscape, however, these forests are the result of a combination of natural processes and human activity, as they have been cultivated intensively for many years and are now a major element in local subsistence strategies.

Referring to these forests and leaning towards an approach in the sense of 'historical political ecology' (Davis 2009; Offen 2004), we will explore how forest protection was debated within predominant conservation discourses in the course of time and link them to current discourses as well as the present local socioeconomic situation. By doing so, we interpret 'forest' and 'nature' not in an essentialist way, but as socially constructed realities and 'geographical imaginations' (Gregory 1994) as well as aspects of the multidimensional relations between human societies and the material world. These relations are strongly influenced by powerful assertive players and in this way reflected and represented in specific meanings, theoretical approaches as well as practices embedded in space and time. 
Our paper explores the objectives and arguments of forest protection concepts from a historical perspective, consideration of the respective socio-political contexts being essential for the analysis. Our aim is, first, to reconstruct the interaction of protection and utilisation by means of historicalcontextual descriptions of forest perception, conservation measures and utilisation practices. Secondly, we want to uncover how specific imaginations reflect the perception of certain actors and organisations determining the discourse and who define which utilisation patterns are classified as beneficial or harmful (Forsyth 2003, 76).

The relevance of our paper lies in the potentially conflict-laden relationship between the present socioeconomic situation of the study area and the current conservation discourse, which recently led to a decision by the Kyrgyz government to create a 'natural park' within the region by 2012 (SAEPFUGKR 2010). Local residents, having lost their social and economic security after the dissolution of the USSR, were not involved in this decisionmaking process. At the same time, most of the local population have been forced to modify their livelihood strategies, shifting from wage work income to subsistence (Schmidt 2008). By contrast, the dominating discourse participants believe that human appropriations of resources threaten the forests and should be cut back. Consequently, the externally introduced protection concept expressly allows only certain human uses of the park for recreation and tourism in a limited area and to a limited extent. However, the essential agricultural and pastoral livelihood practices of the locals are not formally named as legal (LKROPA 2010, art. 23). Against this background we will discuss the question of whether protected walnut-forests are a resource or constraint for local people (Khan and Bhagwat 2010).

\section{Characteristics of the walnut-fruit forest region}

This study relates to a forested area on the northern edge of the Fergana Basin in the Kyrgyz Republic. On the south-facing slopes of the Fergana range of the western Tian Shan about 30,000 ha of mixed forests grow at elevations between 1500 and $2000 \mathrm{~m}$ asl (Musuraliev 1998, 5; see Figure 1).

These forests contain a great variety of woody species, mainly walnut (Juglans regia) and maple (Acer turkestanica), as well as many wild forms of fruit species (Gottschling et al. 2005). It seems remarkable that these forests have survived at all, considering their location on the edge of one of the most densely settled areas in Central Asia and their obvious abundance of wood, nuts and fruit. Human impact has been considerable over a long period, with a substantial effect on fauna and flora. Today, some 50000 people live close to these forests, and their livelihood partly depends on the use of local land and forest resources. The study area was controlled by foreign sovereigns for centuries. It was ruled by the Khans of Kokand during the 18th and 19th centuries, annexed by the Russian Empire in 1876, and incorporated into the Soviet Union in 1924.

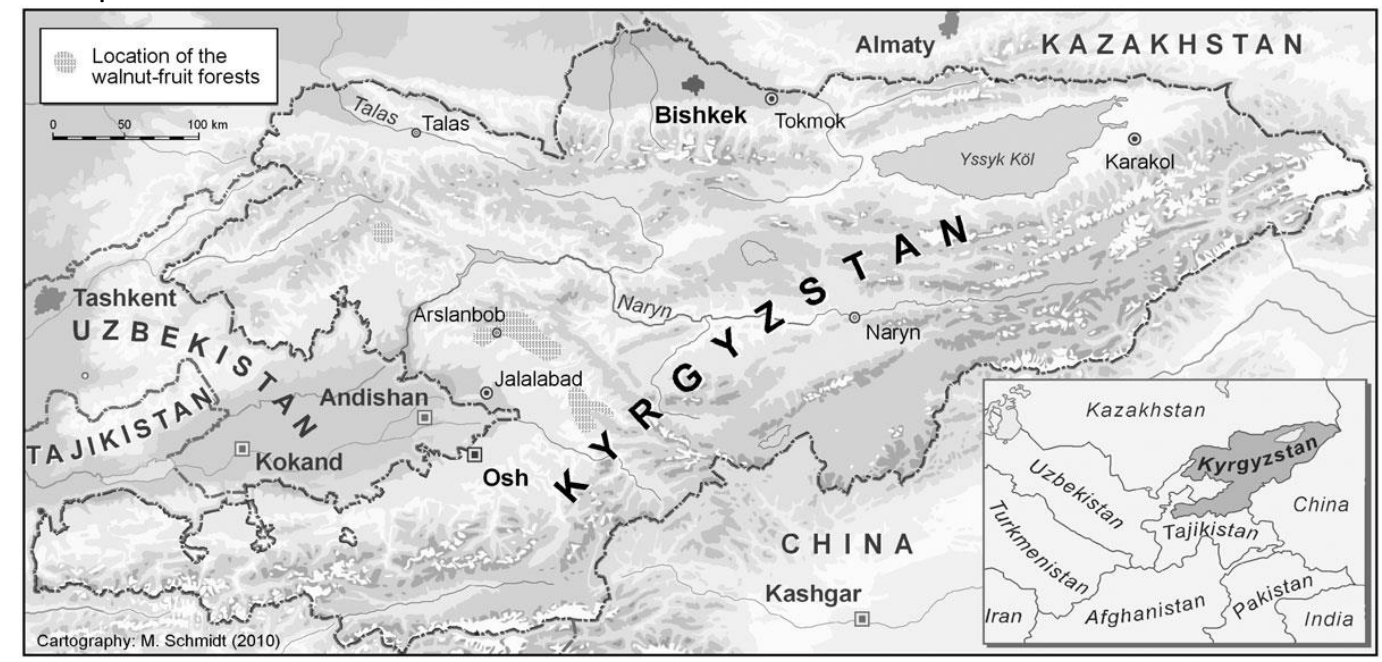

Figure 1 Location of the walnut-fruit forests in Kyrgyzstan 
As a result, the local population had only limited options for autonomous action during the last two centuries. Higher-level authorities and stakeholders established rights of access, possession and use, neglecting local needs and protection practices. Hence with regard to their dominant position within the predominant discourse, they were able to determine which parts of nature were considered worthy of protection or utilisation. To understand the current situation it is important to disclose and deconstruct the reasons for previous prohibitions and constraints. Additionally it is necessary to show that stereotypical conceptions are by no means an ontological given, but are produced in the context of discursive processes that in turn reflect power structures (Mattissek and Reuber 2004, 237; Mattissek 2007).

Our thesis is that concepts for forest protection from the colonial period up to the post-Soviet era did not arise from the understanding of an intrinsic value of nature, but were formed through pragmatic arguments to create control systems over these forests. Powerful actors influenced the creation of specific institutions to achieve their resource related interests. By doing so, only specific forms of human appropriation became legal. For this reason we are not asking for root causes and impacts of environmental change, but how arguments related hereto flow into discourse argumentation and institutional contexts.

\section{Discourse analytical interpretation of written sources}

By applying an interpretative method for the analysis of historical sources, we understand language not only as a 'social practice' (Campbell 2009, 167) but also as 'socially shaped' and 'socially shaping' and in this way as a 'complex social event' (Fairclough 1993, 134, 136). We argue, first, that discourses are dominated by powerful stakeholders and in this way represent the power structure within a society; second, that discourses as supraindividual patterns and structures shape the focused subject linguistically and attribute matter and meaning to it; and, third, that concepts became hegemonic in this way influencing individual speech-based understandings of the subject as well as what is to be considered common sense, knowledge or even truth, socio-cultural and economic practice (Foucault 1972; Fairclough 1995; Hajer 1995; Mattissek and Reuber 2004; McGregor 2005).

We centred on written historical sources from authors and institutions dominating discourses during different epochs. These sources were analysed to detect significant arguments, statements and passages to show the constructed character of the concepts 'forest' and 'nature' and the utilisation forms and conservation efforts deriving from them. The interpretation of the identified text fragments took place under explicit consideration of the wider socio-historical frame, of the authors' institutional context, their social position as well as the addressees and the purpose of the whole text.

Our paper is based on intensive archival research in Bishkek, Tashkent, Osh, Jalalabad and Berlin. There we found scientific papers, minutes of meetings and administrative proceedings of different institutions, legal rights, party reports as well as newspaper articles from colonial and Soviet eras. We inspected recent documents such as scientific articles, laws, intern instructions and annual reports by the state forestry enterprises and other governmental institutions.

\section{The walnut forests under changing discourses}

\section{Forest regulation under Russian colonial rule}

In 1876 the Russian Empire annexed the Khanate of Kokand and incorporated the whole region, including the nut forest area, into the so-called Turkestan Government- General. Driven by the Great Game - Britain and Russia's struggle for supremacy in Central Asia (Hopkirk 2001; Ewans 2004) Russian expansion required reliable knowledge of the natural landscape. Explorers' reports had 
provided the colonists with basic information about relief, climate and natural resources. Remarkably, the newly established forest department recognised the ecological and hence the indirect economic value of the mountain forests of the Fergana region, including the nut trees. Their capacity for regulating the water balance and the protection they provide against denudation and erosion create direct links between processes in mountains and agriculture in irrigation oases (Nalivkin 1883, 65; Navrotskij 1900, III; HFD 1901, 432). Rauner, a former chief of the Board for agriculture and state property of Turkestan and vice-inspector of the Corps of forestry officers wrote:

Because these water sources safeguard the entire agriculture of the Turkestan valleys they require special protection with the aim of preserving the stored water, as far as possible also stabilising water level fluctuations, and maintaining the entire water regime. Mountain forests have an enormous effect ... on the appropriate fluctuations of water level and discharge. (1901, 3f.)

The oldest documents dealing explicitly with specific conservation issues are Russian scientific publications, newspaper articles and administrative records, which led the colonial powers to initiate a debate about the 'right' and 'wrong' way of managing the forests. The documents are often pervaded by laments about the 'sad state' (Lisnevskij 1884, 51) and diminishing size of the forests due to uncontrolled felling, fire clearing and forest grazing, and by scenarios of social conflicts likely to result from the lack of natural forest regeneration, the decreasing size, and the subsequent threat to water supplies (Nalivkin 1883, 16: 62f; 17: 66; Korzhinskij 1896, 42; Navrotskij 1900, III; Rauner 1901, 4ff.; HFD 1901, 432, 456). A scientific paper cites the Muslim population's fatalistic attitude to the issue of forest property and use as a cause:

The forests growing in the mountains were provided by Allah for the benefit of all people inhabiting the country, and because they do not belong to a specific individual they can be exploited ... by anyone living there... For Allah will plant new forest to replace what has been cleared. (Lisnevskij 1884, 51)

In conjunction with the imputed incompetence of the local administration and population resulting from ignorance about the natural conditions, theoretical assumptions about the ecological and economic relevance of the forests were the starting point for protective measures dictated by the colonial administration. Not least in expectation of population growth due to Russian immigration and increasing food demands, forests were legally codified as state property, and protection of the mountain forests became a key task of the colonial forestry administration (Bannikov 1969, 18; SCF 1899, 32; HFD 1901, 431, 436; MASP 1902; Makarov 1940, 3). Given the state's primary interest in conserving 'protective forests' as the 'protectors of water resources that give life to Turkestan' (Navrotskij 1900, III) and the overall economic significance of cotton crops, forest exploitation for immediately economic purposes was explicitly given secondary importance (Nalivkin 1883, 78; Rauner $1901,11)$. For a long time the opinion prevailed in the forestry administration that the mountain forests 'neither have, nor can have, any economic importance' (HFD 1901, 433). Selective exploitation of the forests did not begin until the late 19th century. It focused on burls, which were exported to destinations as far away as Marseilles, France. This shows a paradigm shift from conservation to immediate economic valorisation within the forest administration (Nalivkin 1883, 65, 69; Navrotskij 1895,1898 ; Korzhinsky 1896, 40; BASPT 1915), as the following quote from a forestry director shows: in future, the fear that a tree would die as a result of burl harvesting would not deserve attention 'since the value of a cut burl was many times that of the tree' (HFD 1901, 471). Despite the official protection rhetoric, the nut forests gradually became a fixed item in the state budget, with not only timber yields but also payment for usufruct rights representing major sources of revenue.

\section{Planned nut forest appropriation in the Soviet Union}

After 1917, the building of Soviet society drew on interpretations of Marxist-Leninist theories, which developed a historically unprecedented economic, political and societal model and also formulated a 
specific understanding of nature. During the seven decades of the Soviet system, the dominant interpretations of nature and society's treatment of it did not stay static, yet their general trend remained unchanged. Nature was described in terms such as 'chaotic, free of sense . . . hostile, alien and wild' (Bolotova 2008, 58), and its discourse-determining importance lay primarily in its unlimited store of resources. Accordingly, its meaning and value emerged only when it was appropriated and processed by humans using creative technologies. Technical development measures were therefore considered to be essential instruments in building socialist society. Key importance was ascribed to certain natural regions because of their intrinsic ecological potentials for protection and regulation, which were to be protected for macroeconomic reasons (Makarov 1940, 4).

Collectivisation measures in the first half of the 1930s brought an intensive commodification of the nut forests. Although their ecological importance was recognised, it was subordinated by the emphasis on immediately utilisable forestry potentials (Lupinovich 1949, 25; SCUSSR et al. 1991, 72, 177):

The economic importance of the nut forests . . is exceedingly great and varied. The nut stands, supplemented by wide areas of wild apple, plum, rose hip, pear and other trees, ... give this forest massif an extraordinary economic significance. (Momot 1940, 30)

The damaging impact of timber extraction during the first socialist decades led to the decision to designate the nut forests as a zakaznik - a protected area with restricted use - in 1945. A specific management strategy was developed that explicitly permitted forestry enterprises (leskhozes) to continue appropriating forest resources and formulated directives to safeguard the forest's runoff and water storage function. Again the nut forests came into focus in connection with their aforementioned hydrological functions and their consequent relevance for largescale irrigation projects to expand cotton growing (Lupinovich 1949, 20, 25).

Public discussion of the importance and treatment of nature began to change after Stalin's death in 1953 and increasingly in the 1970s and 1980s when ecological problems became more visible and modernisation met with more international criticism. Greater frequency of co-occurrences such as 'careful' and 'rational use', as well as phrases such as 'natural wealth', which suggest an essentialist value of nature, indicate a cautious wateringdown of the economistic view of nature. Nevertheless, the predominant perception was that the driving forces maintaining socialist society were the modernisation paradigm and resource-based technological progress, whereas ecological interrelationships were of subsidiary importance (SCKSSR and ASKSSR 1985, 6; Obertreis 2008). Accordingly, the Supreme Soviet of the Soviet Union $(1972,8)$ justified the necessity of conservation measures by their future economic impact.

So in the preamble to Soviet forest legislation, the economic potential of the forests is accorded predominance over other factors (CKSSR 1950; FFLUSSR 1977). The term 'forests of the nut industry zones' (lesa orekhopromyslovykh zon) found in Article 15 of the FFLUSSR (1977) highlights the immediate economic importance of these forests. Furthermore, protection measures are justified by the necessity of protecting specific forest functions, not for the protection of the forest in its own right.

Remarkably, the USSR considered itself a pioneer of nature protection for two reasons. First, it denied capitalism any protective capacity because of the latter's inherent orientation towards self-interest. Second, it had already addressed the issues in its founding years, in a manner similar to the goals later formulated by UNESCO (2002), by designating specified types of area with different protection levels, interlinked as components of a nationwide network of protected areas (Rashek et al. 1983, 10). The zakaznik concept limited management to certain spheres and periods, making possible what was known as a 'socialist utilisation of nature' (Trofimov and Romanov 1981; Shaposhnikov 1967, 5ff.; Rashek et al. 1983, 23; Meessen 1988, 42). 
In connection with the development of tourism from the 1960s onwards, an alternative, aesthetically oriented perception of the nut forests prevailed, with positive publicity effects. Brochures and guidebooks referred to the forests in sensuous terms:

The crowns of the trees entwine, serpentine paths seem to wind through green tunnels, and the sun barely penetrates the leafy canopy to reach the ground. The air is saturated by the mellow aroma of walnut. Silence prevails, somewhere only disturbed by the thunder of a wild river or waterfall, the murmur of a stream. (Vernadskij 1972, np)

Linguistic constructions of such idealised nature scenarios should be understood as economically motivated attempts to instrumentalise an understanding of nature that ascribes to it an essentialist value, serving as advertisements to attract visitors.

\section{Continuity and paradigm shift in the post-Soviet phase}

In view of the polluted and ruined landscapes in the USSR, the end of the socialist experiment brought great hopes for a general improvement of the environmental situation. It was hoped that the introduction of a market economy would lead to more efficient use of resources and that democratisation would increase attention to stakeholder concerns (Shaw and Oldfield 1998, 164). By and large, the Kyrgyz Republic took over concepts and nomenclature of Soviet environmental protection and incorporated them into national laws, at the same time trying to achieve compatibility with international standards. Since independence in 1991, management, strategies and utilisation of the nut forests, as well as ideas about their relevance, have demonstrated persistence and continuity, on the one hand, and new conservation paradigms and actors, on the other. At the same time there are not enough funds and staff to implement these conservation concepts and ensure that they are complied with.

At the present time, the leskhozes, founded in the late 1940s, are still responsible at the local level for forestry use of the state-owned forests. Owing to tight budgets and drastic staff cutbacks, the leskhozes are now finding it increasingly difficult to manage and monitor protection regulations. Besides, job losses and reduced social security benefits have led to insecurity and poverty at the individual level, making it necessary to modify livelihood strategies, one of which was utilisation of local land and forestry resources. As already shown elsewhere (Fisher et al. 2004), the importance of forestry resources increased for individual households. At present, the greatest dangers to the longterm survival of the nut forests are quoted illicit burl sawing, unregulated cutting of timber and fuelwood, as well as haymaking and forest grazing (Schmidt 2005; Eastwood et al. 2009; SAEPFUGKR 2010). Emphasis on the uniqueness of Kyrgyzstan's nut forests and their importance for soil protection and water cycle (Venglovskij 1998, 76) remains a persistent element of an environmental narrative right up to the present time (Balbakova nd; Shukurov and Balbakova 2009), as does the notion that the nut forests are relicts from Tertiary time (Kolov 1998, 59), which was recently disproved by Beer et al. (2008), or even the original home of most of our fruit species (Succow 2004, 30; SAEPFUGKR 2010). Addressing target groups seeking 'pure nature', tourist companies promise 'unspoilt, preserved nature', alluding to the longterm protected status of the forests (Advantour 2009; CBT 2009).

Now that Kyrgyzstan is easily accessible, Western scientists and international environmental organisations are new actors in research and development projects. At the same time, they import their ideas of nature conservation and meanwhile dominate the discourse about the (global) importance of the nut forests and the 'proper' way of managing them. Referring to Vavilov's statement that Central Asia is one of eight worldwide origins of useful plants (Hawkes 1998), Davis et al. (1995) identified the mountains of Central Asia as a global 'hotspot of biodiversity', containing more than 300 species of wild fruit and nuts (Eastwood et al. 2009, 5). The nut forests play a special role within this hotspot because of their great variety of woody species and habitats. Eastwood et al. $(2009,8)$ even credit them with 'global significance' because of their importance as an 'international genetic 
resource'. Although not explicitly named, a broader notion of the commodification of the forests is immanent in such statements (Willems-Braun 1997): for instance, the necessity of safeguarding species diversity and especially genetic codes with a view to future economic utilisation of the material. In this way, the authors are internationalising the nut forests by rating global interests - genetic resources conservation - higher than local concerns: 'As the largest and best remained relict forests the walnut-fruit forests are of global importance. [. . . [They] store rich genetic resources [. . . ] for the breeding of new species' (SAEPFUGKR 2010,6). To a large extent, Kyrgyz members of the scientific community and the forestry administration have rapidly adopted the ideas and terminology of Western conservationists. For example, Venglovskij $(1998,76)$ advocated 'sustainable forest management', while the most recent statutes of a state forest farm specify various measures to maintain 'sustainability' (ustojchivost') and 'biodiversity' (biologicheskoje raznoobrazie) as key tasks (SFA 2006, 15). In view of the ecological uniqueness that seems to be disappearing as a result of intensive forest use by the local population, Kyrgyz and international researchers are demanding world natural heritage status for the forests and the creation of a preserve area. It seems that the Kyrgyz government will achieve the second demand by proclaiming a 'natural park' by 2012 (SAEPFUGKR 2010). However, this would mean putting certain areas under strict protection and reducing or even banning forest uses by local residents for economic purposes.

\section{Conclusion}

By presenting examples of predominant leitmotifs, arguments and terms of certain historical discourses we proved our hypothesis that the forest protection policies did not derive from an understanding of an essentialist value of nature, but from pragmatic, primarily economic motives, which allowed specific human appropriations (Table 1).

Table 1 Protection and utilisation concepts for walnut-fruit forests in Kyrgyzstan over time

\begin{tabular}{|c|c|c|c|}
\hline Era & Concept & Legal implication & $\begin{array}{l}\text { Leitmotif and } \\
\text { predominant lines of } \\
\text { argument }\end{array}$ \\
\hline $\begin{array}{l}\text { Colonial period } \\
\text { Russian czardom } \\
\text { (1876-1917) }\end{array}$ & $\begin{array}{l}\text { 'Protectors of water } \\
\text { resources that give } \\
\text { life to Turkestan' }\end{array}$ & $\begin{array}{l}\text { Forests as state property } \\
\text { with safeguard functions } \\
\text { but without a legal title } \\
\text { as protected areas }\end{array}$ & $\begin{array}{l}\text { Preservation of forests' capacity for water } \\
\text { balance regulation and erosion control to } \\
\text { secure the regional ecological suprastructure } \\
\text { Reason: macroeconomic prosperity through } \\
\text { securing cotton production on irrigated areas } \\
\text { as part of the colonial project }\end{array}$ \\
\hline $\begin{array}{l}\text { Socialist era } \\
\text { Soviet Union } \\
(1917 / 24-1991)\end{array}$ & Zakaznik & $\begin{array}{l}\text { Forests with safeguard } \\
\text { functions and restricted } \\
\text { use as state-onved } \\
\text { protected areas, } \\
\text { equipped with a legal } \\
\text { title and de facto } \\
\text { subdivided into } \\
\text { protected and } \\
\text { exploitable areas }\end{array}$ & $\begin{array}{l}\text { Preservation of forests' capacity for water } \\
\text { balance regulation and erosion control to } \\
\text { secure the regional ecological suprastructure } \\
\text { Immediate resource appropriation for economic } \\
\text { purposes of the forestry sector } \\
\text { Reason: macroeconomic prosperity through } \\
\text { securing cotton production on irrigated areas } \\
\text { and immediate forest valorisation as the base } \\
\text { of socialist project's long-term success }\end{array}$ \\
\hline $\begin{array}{l}\text { Capitalism } \\
\text { Kyrgyz Republic } \\
\text { (since 1991) }\end{array}$ & $\begin{array}{l}\text { Zakaznik, natural park } \\
\text { (scheduled for 2012) }\end{array}$ & $\begin{array}{l}\text { Forests with safeguard } \\
\text { functions and restricted } \\
\text { use as state-owned } \\
\text { protected areas, } \\
\text { equipped with a legal } \\
\text { title and de facto } \\
\text { subdivided into } \\
\text { protected and extensive } \\
\text { utilisable areas }\end{array}$ & $\begin{array}{l}\text { Preservation of forests' capacity for water } \\
\text { balance regulation and erosion control to } \\
\text { secure the regional ecological suprastructure } \\
\text { Preservation of the globally important forest } \\
\text { species diversity } \\
\text { Imrnediate resource appropriation for economic } \\
\text { purposes of the forestry sector and limited } \\
\text { recreation and tourist activities } \\
\text { Restriction of local utilisation practices } \\
\text { Reason: maintaining and restoring regional } \\
\text { ecological integrity, safeguarding the genetic } \\
\text { potentials for further economic purposes and } \\
\text { acceptance of the recreational meaning of } \\
\text { the forests }\end{array}$ \\
\hline
\end{tabular}


Regulated utilisation, based on protection-oriented arguments, was first introduced under colonial rule. Legal legitimation of utilisation modes primarily depended on their compatibility with protection aims and followed the political and economic logic of the colonial power. The gradually watered-down leitmotif of the colonial mountain forest discourse could be described as 'conserving the protective forests', and its arguments were primarily directed towards maintaining the macroeconomic stability of the entire region as the base of successful colonisation. The aforementioned references contained no indication that the forests should be protected because of the putative intrinsic value of nature (priroda). The Soviet conservation strategy aimed to preserve the nut forests because of their dual economic importance: their protective functions and the direct economic appropriation that became more intensive, better coordinated and lastly took precedence over conservation issues. The zakaznik status accorded to the forests permitted their use for purposes of forestry and subsequently tourism, alongside conservation aims. The primacy of appropriation derives from the specifically Soviet development model and requires protective measures to be supplemented by compensatory afforestation to safeguard long-term resource use. This showed notable affinity with the current sustainability discourse and the 'biosphere reserves' approach.

At present, the forests formally still belong to the same protection category as in Soviet times, but continuous measures are not being implemented to any appreciable extent. Forest management is substantially less intensive than during the Soviet era, whereas unregulated resource extraction has increased. At the same time, forest utilisation has become more important as an income source for the local population.

Consequently, the present state of the forests has been substantially affected by long-term human use in discontinuous form and extent. If the forests' structural significance for local economies is ignored, concepts operating with the basic objective of restoring the forests in a natural shape as well as of protecting biodiversity and genetic resources for global purposes will generate new rivalries and conflicts. The 'natural park' model itself and the decision making process characterised by the exclusion of the local population implies such threats. Rather, in view of the long-term human impact, the forests must be understood primarily as a cultural landscape, and their economic relevance has to be recognised. Consequently the aims, instruments and terminologies of prospective protection concepts must be adapted to this understanding and formulated with the involvement and participation of local stakeholders. We have demonstrated that historical discourse analysis of written sources is a suitable tool to uncover the trajectories and genesis of current ideas of 'nature' and 'environmental protection'. By systematising arguments within a discourse, by identifying actors and their interests as well as their assertiveness within the discourse, this approach is helpful to explain why and how specific ideas became established and others not. In this sense the approach can support the early detection of resource-related conflicts and processes of civil conflict management.

\section{Acknowledgements}

The present paper is a product of a collaborative research project named "The impact of the transformation process on human- environmental interactions in Southern Kyrgyzstan", carried out by an interdisciplinary group of scholars from Germany (Berlin, Hamburg, Bonn) and Kyrgyzstan (Bishkek, Osh). We want to express our gratitude to the Volkswagen Foundation for their support of this project. Thanks go also to the people of Arslanbob, Gumhana, Kyzyl Unkur and Kara Alma for their hospitality and their patience in answering our endless questions. Furthermore we want to thank the anonymous reviewers for their valuable comments. 


\section{References}

Advantour 2009 Arslanbob (http://www.advantour.com/ kyrgyzstan/arslanbob.htm) Accessed 24 June 2009

Balbakova F N nd Klasternyje uchastki orekhoplodovykh lesov 'Sary Chelek', 'Kara Alma', 'Arstanbab' kak ob"ekty vsemirnogo prirodnogo naslediya

Bannikov A G 1969 Zapovedniki i okhrana prirody in Bannikov A G ed Zapovedniki SSSR Moscow 120

BASPT (Board for Agriculture and State Property in Turkestan) 1915 Zhurnal Vtorogo Soveshshaniya po ustroystvu Bazar- Kurganskoy lesnoy dachi, Bazar-Kurganskago Lesnichestva, Ferganskoj oblasti 31 August Tashkent

Beer R, Kaiser F, Schmidt K, Ammann B, Carraro G, Grisa E and Tinner W 2008 Vegetation history of the walnut forests in Kyrgyzstan (Central Asia): natural or anthropogenic origin? Quaternary Science Review 27 621-32

Blaser J, Carter J and Gilmour D eds 1998 Biodiversity and sustainable use of Kyrgyzstan's walnut-fruit forests IUCN, Cambridge

Bolotova A 2008 Die Geologen: Kolonisatoren am Lagerfeuer. Selbstbild und Naturverständnis in der Sowjetunion Osteuropa Zeitschrift für Gegenwartsfragen des Ostens, Sonderdruck 58 57-67

Campbell D 2009 Discourse analysis in Gregory D, Johnston R, Pratt G, Watts M and Whatmore S eds The dictionary of human geography Wiley-Blackwell, Chichester 167-8

CBT (Kyrgyz Community Based Tourism Association) 2009 Forests of Arslan-Bob (http://www.cbtkyrgyzstan.kg/index.php? option=com_content\&task=view\&id=72\&Itemid=84) Accessed 11 August 2009

CKSSR (Constitution of the Kyrgyz SSR) 1950 in High Board of the Kyrgyz SSR ed Sbornik zakonov Kirgizskoj SSR i ukazov prezidiuma Verkhovnogo Soveta Kirgizskoj SSR 1938-1949 Frunze 17-38

Davis D K 2009 Historical political ecology: on the importance of looking back to move forward Geoforum 40 285-6

Davis S D, Heywood V H and Hamilton A C 1995 Centres of plant diversity: a guide and strategy for their conservation. Vol. 2: Asia, Australia and the Pacific WWF/IUCN, Cambridge

Eastwood A, Lazkov G and Newton A 2009 The red list of trees of Central Asia Fauna \& Flora International, Cambridge

Ewans M ed 2004 The great game. Britain and Russia in Central Asia RoutledgeCurzon, London

Fairclough N 1993 Critical discourse analysis and the marketization of public discourse: the universities Discourse \& Society 4 133-68

Fairclough N 1995 Critical discourse analysis Longman, London

FFLUSSR (Fundamental Forests Legislation of USSR and the Republics of the Union) 1977 Moscow

Fisher R J, Schmidt K, Steenhof B and Akenshaev N 2004 Poverty and forestry: a case study of Kyrgyzstan with reference to other countries in West and Central Asia Livelihood Support Programme working paper FAO, Rome

Forsyth T 2003 Critical political ecology: the politics of environmental science Routledge, London

Foucault M 1972 The archeology of knowledge and the discourse on language Pantheon Books, New York

Gottschling H, Amatov I and Lazkov G 2005 Zur Ökologie und Flora der Walnuß-Wildobst-Wälder in Süd-Kirgisistan Archiv für Naturschutz und Landschaftsforschung 44 85-130

Gregory D 1994 Geographical imaginations Blackwell, Cambridge MA 
Hajer M 1995 The politics of environmental discourse Oxford University Press, Oxford

Hawkes J G 1998 Back to Vavilov: why were plants domesticated in some areas and not in others? in Damania A B, Valkoun J, Willcox G and Qualset C 0 eds The origins of agriculture and crop domestication ICARDA, Aleppo

HFD (Head of Forest Department) 1901 Lesnoe delo v Turkestane Lesnoj Zhurnal 3 31-472

Hopkirk P 2001 The great game: on secret service in High Asia Oxford University Press, Oxford

Khan M S and Bhagwat Sh A 2010 Protected areas: a resource or constraint for local people? Mountain Research and Development 3 14-24

Kolov 01998 Ecological characteristics of the walnut-fruit forests of Southern Kyrgyzstan in Blaser J, Carter J and Gilmour D eds Biodiversity and sustainable use of Kyrgyzstan's walnut-fruit forests IUCN, Cambridge 59-61

Korzhinskij S 1896 Ocherki rastitel'nosti Turkestana I-III. Zakaspijskaya oblast', Fergana i Alai. Zapiski Imperatorskoj Akademii Nauk VIII. Seriya po Fiziko-Matematicheskomu Otdeleniyu 4. St Petersburg

Lisnevskij V I 1884 Gornye lesa Ferganskoj oblasti Novyj Margelan

LKROPA (Law of the Kyrgyz Republic 'On protected areas' (draft)) 2010 Bishkek (http://www.nature.kg/index.php? option=com_content\&view=article\&id=146\%3A-l-r-\&catid= 34\%3A2009-01-28-16-47-09\&Itemid=69\&lang=ru) Accessed 12 October 2010

Lupinovich I S 1949 Osnovnye rezul'taty rabot Yuzhno-Kirgizskoj kompleksnoj ekspeditsii in Academy of Science, Board for Research on Production Forces ed Plodovye lesa yuzhnoj Kirgizii i ikh ispol'zovanie. Trudy Yuzhno-Kirgizskoj ekspeditsii 1 Moscow 7-31

Makarov V N 1940 Zapovedniki SSSR Moscow

MASP (Ministry for Agriculture and State Property) 1902 Instruktsiya po upravleniyu gosudarstvennymi imushshestvami i po zavedyvaniyu sel'skokhozjajstvennoyu tschast'yu $\mathrm{v}$ Turkestanskom krae Lesnoj Zhurnal 6 1351-77

Mattissek A 2007 Diskursanalyse in der Humangeographie - 'State of the Art' Geographische Zeitschrift 95 37-55

Mattissek A and Reuber P 2004 Die Diskursanalyse als Methode in der Geographie - Ansätze und Potentiale Geographische Zeitschrift 92 227-42

McGregor A 2005 Negotiating nature: exploring discourse through small group research Area $37423-$ 32

Meessen H 1988 Naturschutz in Georgien Geographische Rundschau 40 38-43

Momot S M 1940 Sovremennoe sostoyanie khozyajstva v orekhovykh lesakh yuzhnoj Kirgizii in Collective of Research Associates of the Arslanbob-Base Station of the National Scientific Research Institute on Dry Tropics and State Commissariat of USSR for Agriculture eds Gretskij orekh yuzhnoj Kirgizii Tashkent 30-45

Musuraliev T M 1998 Forest management and policy for the walnut-fruit forests of the Kyrgyz Republic in Blaser J, Carter J and Gilmour D eds Biodiversity and sustainable use of Kyrgyzstan's walnut-fruit forests IUCN, Cambridge 3-17

Nalivkin V 1883 Zametki po voprosu o lesnom chozyajstve v Fergane Turkestanskiya Vedomosti (16) 62-3, (17) 65-6, (18) 69-70, (20) 77-8

Navrotskij S 1895 Vedomost' obshshyaya pereuchyotu naplyvov na orekhovykh derev'jakh. Oblasti: Ferganskaya i Syr- Darinskaya. Uezdy: Andizhanskij, Namanganskij i Tashkentskij Tashkent

Navrotskij S 1898 Vedomost' ploshshyadyam lesnykh uchastkov v lesnykh dachakh Turkestanskago kraya Tashkent 
Navrotskij S 1900 Zapiska predstavlennaya Lesnichim 1 razryada Samarkandskoj Oblasti Navrotskim v 3-e zasedanie 1-go Turkestanskogo Sezda Lesnichikh v 1899 godu in Board on Agriculture and State Property in the Turkestan Territory ed Materialy dlya lesnoj statistiki Turkestanskago kraya. Lesnyya dachi Turkestanskago kraya Tashkent II-IV

Obertreis J 2008 Der 'Angriff auf die Wüste' in Zentralasien. Zur Umweltgeschichte der Sowjetunion Osteuropa Sonderdruck 58 37-56

Offen K H 2004 Historical political ecology: an introduction Historical Geography 32 19-42

Rashek V L, Syroechkovskij E E and Jazan J P 1983 Zapovedniki SSSR kak prirodookhranitel'nye uchrezhdeniya in Borodin A M and Syroechkovskij E E eds Zapovedniki SSSR Moscow 9- 25

Rauner S Yu 1901 Gornye lesa Turkestana i znachenie ikh dlya vodnago khozyajstva kraya. Raboty po obleseniyu gornykh sklonov s cel'ju prekrashsheniya silevykh potokov St Petersburg

Pickles J and Smith A eds 1998 Theorising transition Routledge, London

SAEPFUGKR (State Agency on Environment Protection and Forestry under the Government of the Kyrgyz Republic) 2010 Natsional'naya strategiya sokhraneniya biologitsheskogo raznoobraziya Kyrgyzskoj Respubliki na 2011-2025 gg. Draft, Status of April 2010 (www.nature.kg/images/files/str_bioraz. doc) Accessed 12 October 2010

SCF (Statistical Committee of Fergana) 1899 Obzor Ferganskoy oblasti za 1897 god Novyj Margelan

Schmidt M 2005 Utilisation and management changes in South Kyrgyzstan's mountain forests Journal of Mountain Science 2 91-104

Schmidt M 2008 Political ecology in high mountains: the web of actors, interests and institutions in Kyrgyzstan's mountains Colloquium Geographicum 31 139-53

SCKSSR and ASKSSR (State Committee of the Kyrgyz SSR for Forestry and Academy of Science of the Kyrgyz SSR) eds 1985 Krasnaya Kniga Kirgizskoj SSR Frunze

SCUSSR, NAL, CCCF and FEIF (State Committee of the USSR for Forests, National Association 'Lesproekt', Central Corporation for Control of Forestry, and First Expedition for Inventory of Forests) 1991 Proekt organizatsii i razvitiya lesnogo khozyajstva Kirovskogo Leskhoza YuzhnoKirgizskogo Upravleniya po orekhovodstvu i pererabotke produktsii pobochnogo pol'zovaniya lesom proizvodstvennogo leskhozyajstvennogo ob"edineniya 'Kirgizles'

SFA (Statute of the Forestry 'Arstanbap-Ata' of the Department for Forest-Development and the Regulation of Game- Resources of the Jalal-Abad-Territory, Governmental Agency for Preservation of the Environment and Forestry of the Kyrgyz Republic) 19 October 2006

Shaposhnikov L K 1967 Postoyannye zakazniki v sisteme okhrany prirody SSSR in Ministry of Agriculture of USSR Academy of Science of USSR and Central Laboratory for Conservancy eds Primechatel'nyje Prirodnye Landshafty SSSR i ikh okhrana. Botanicheskie, geologicheskie, ozernye i zoologicheskie zakazniki SSSR Moscow 5-12

Shaw D J B and Oldfield J 1998 The natural environment of the CIS in the transition from communism Post-Soviet Geography and Economics 39 164-77

Shukurov E D and Balbakova F N 2009 Ekologo-Prosvetitel'skaya Deyatel'nost' Osobo Okhranyaemykh Prirodnykh Territorij (http://www.zk.ru/murek/balbakova.htm) Accessed 6 March 2009 Succow M 2004 Schutz der Naturlandschaften in Mittelasien Geographische Rundschau 56 28-34

Supreme Soviet of the Soviet Union 1972 Beschluss des Obersten Sowjet der UdSSR vom 20.09.1972 'Über Maßnahmen zur weiteren Verbesserung des Schutzes der Natur und zur rationellen Ausnutzung der Naturressourcen' in Akademie für Staats- und Rechtswissenschaften der DDR ed Beschlüsse und andere Dokumente der KPdSU und des Sowjetstaates zum Umweltschutz. Aktuelle Beiträge der Staats- und Rechtswissenschaft 250 Potsdam Babelsberg 8-14 Trofimov P M and Romanov V S 1981 Sotsialisticheskoe Prirodopol'zovanie Minsk

UNESCO 2002 Biosphere reserves: special places for people and nature UNESCO, Paris 
Venglovskij B I 1998 Potentials and constraints for the development of the walnut-fruit forests of Kyrgyzstan in Blaser J, Carter J and Gilmour D eds Biodiversity and sustainable use of Kyrgyzstan's walnut-fruit forests IUCN, Cambridge 73-6

Vernadskij G $\quad$ M 1972 Marshruty Ferganskoy doliny Moscow (http://www.skitalets.ru/books/fergan_dolina/index.htm) Accessed 24 June 2009

Willems-Braun B 1997 Buried epistemologies: the politics of nature in (post)colonial British Columbia Annals of the Association of American Geographers 87 3-31 